\title{
Transatlantica
}

Revue d'études américaines. American Studies Journal

\section{A French Daily Backed by American Interests: Le Matin, 1884-1890}

Dominique Pinsolle

\section{(2) OpenEdition}

1 Journals

\section{Electronic version}

URL: https://journals.openedition.org/transatlantica/6463

DOI: 10.4000/transatlantica.6463

ISSN: 1765-2766

\section{Publisher}

Association française d'Etudes Américaines (AFEA)

\section{Electronic reference}

Dominique Pinsolle, "A French Daily Backed by American Interests: Le Matin, 1884-1890", Transatlantica [Online], 1 | 2013, Online since 16 February 2014, connection on 01 February 2023. URL: http:// journals.openedition.org/transatlantica/6463 ; DOI: https://doi.org/10.4000/transatlantica.6463

This text was automatically generated on 1 February 2023.

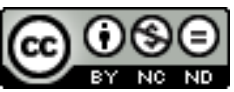

Creative Commons - Attribution-NonCommercial-NoDerivatives 4.0 International - CC BY-NC-ND 4.0 https://creativecommons.org/licenses/by-nc-nd/4.0/ 


\title{
A French Daily Backed by American Interests: Le Matin, 1884-1890
}

\author{
Dominique Pinsolle
}

1 The American businessman John William Mackay (1831-1902), who made his fortune working the goldfields of Nevada, was world-famous as one of the "Bonanza Kings." Less known is his interest in the French press. In 1883, he funded a newspaper called The Morning News. Its French edition, Le Matin, later became one of the most important newspapers in France (Pinsolle, 2012). Le Matin quickly drew the attention of new American businessmen like the Coudert brothers, whose law firm was world-renowned. But six years after its creation, all the American shareholders of Le Matin were gone and the newspaper was left to its Parisian editor. The case of The Morning News and Le Matin is a unique example of an attempt to export to France methods developed by American businessmen in the United States. Mackay and the Coudert brothers wanted to reach commercial goals by using a newspaper published in Paris. The story of the first years of The Morning News and Le Matin reveals their views of the role of the press and the difficulties they had to confront in a foreign country. In 1883-1884, the American backers of the two papers were already rich and powerful in the United States. They thought that they could spread their influence overseas thanks to the press, which was a flourishing sector in both countries. Newspapers were seen more and more (in the United States and in France) as a way to earn money and to gain influence. But Mackay and the Coudert brothers underestimated the gap between France and their own country. Their failure, after 1890, proves that money was not enough for them to become influential in France and raises the issue of the link between business and politics during the Gilded Age: beyond money, what is the importance of other factors, like social networks, personal relationships or cultural proximity? The study of the "American" Matin era allows us to understand how money can be useful for American businessmen to reach certain specific short-term commercial goals, while remaining inadequate to enjoy a lasting impact on French politics and business. More specifically, the role of The Morning News during the commercial war between Mackay and Bennet's Commercial Cable Company and Jay Gould's Western Union in 1883-1884 must be seen as an extension of a US economic rivalry into France. And even if they probably wanted 
to promote the construction of the Panama canal, the Coudert brothers hoped to earn money directly by running the company "Le Matin" and, maybe, to spread their activities in France. But the buyout of the newspaper by its Parisian editor in 1890 was a failure for them, and proved that the power of American businessmen could not be exported so easily.

\section{The Morning News and Le Matin: two weapons during the commercial war waged by the Commercial Cable Company}

\section{The press as an instrument: Mackay and Bennett's view of newspapers}

The Morning News was created in 1883 by two famous American associates: John W. Mackay and James Gordon Bennett, Jr., owner of the New York Herald Tribune - the continental edition of the New York Herald and the ancestor of the International Herald Tribune $^{1}$. Although the press was more and more profitable, neither saw these newspapers as a way to earn money, but as a weapon to win the commercial war they were waging against Jay Gould's Western Union and the big news agencies (Havas, Reuters, Continental and Associated Press). The conditions of the creation of The Morning News and Le Matin reveal the role assigned to the press by two businessmen representative of the Gilded Age.

John Mackay was the "American dream" personified. He was born in Dublin in 1831 and emigrated to New York when he was nine years old. Ten years later, during the gold rush, he moved to Nevada, where he mined, with his associates, the famous Comstock Lode. In 1873, he discovered a huge field of gold and silver, which quickly took the name of "Big Bonanza." Thanks to the Comstock Lode, Mackay became one of the richest men in the world (Makley, 2009, IX). In 1876, he moved with his wife to New York, where he probably met James Gordon Bennett, Jr., the son of the New York Herald's founder.

Bennett was born in New York but lived mainly in Europe during his childhood. He came back to United States when he was 20 years old, and joined the New York Herald in 1866. Under his direction, the Herald became world-famous thanks to the mission led by Stanley to find the explorer Livingstone in Africa between 1869 and 1871. At the beginning of the 1880's, Bennett stayed regularly in Paris (Crouthamel, 1989, 49-51), where Mackay also used to spend time (Smith and Tingley, 1998, 267).

5 Mackay and Bennett wanted to break the monopoly of Western Union, the biggest American telegraph company, which was owned by the railroad tycoon Jay Gould. Mackay, who owned the Postal Telegraph, was an important rival of Gould. As for Bennett, he wanted to free his newspaper, the New York Herald Tribune, published in London, from the big news agencies. In 1883, Bennett and Mackay created the Commercial Cable Company, and started battling Western Union. At the end of the year, the American Secretary of State authorized them to lay a new transatlantic cable (Griset, 1996, 85-89).

6 Mackay and Bennett needed to promote their Company to break the monopoly of the Western Union. The New York Herald crusaded for the Commercial Cable Company, but 
it was not enough to attack the big news agencies at the same time. Paris was the ideal place to launch a new paper independent from these agencies and promote the Commercial Cable Company. No French newspaper was directly connected to London which was the center of the world telegraph network. The entire French press was mainly dependent on Havas for their foreign news. Even the papers published in English, like Galignani's Messenger, had no telegraph connection with London (CooperRichet, 2006, 39-51).

\section{A newspaper as a profitable company: the creation of Le Matin by Samuel S. Chamberlain and William A. Hopkins}

7 Bennett needed a man he could trust to launch the Morning News. He called on a wellknown American journalist he met at the Herald, Samuel Selwyn Chamberlain (1851-1916), who moved from New York to Paris in 1883. Contrary to the owners of the Commercial Cable Company, Chamberlain was interested in creating a profitable media company. His conception of The Morning News was different from Mackay and Bennett's point of view. They let him control the newspaper with their money, because they did not care about running the company. But this situation was possible only because Mackay and Bennett could trust Chamberlain, who was closely linked to the owner of the New York Herald.

8 Like Bennett, Chamberlain was then famous for his professional talents, his dandy lifestyle and his taste for alcohol and life in high society. He began as a journalist at the New York Herald (1875-1879) and then joined the New York World (1879-1880) and the Evening Telegram (1881-1883) (Featherston, 1978, 38-42). With the financial background of Mackay, Chamberlain accepted the assignment to launch a newspaper which would be directly linked to London. William Alonzo Hopkins (1840-1928), a friend of Chamberlain's living in Paris, also invested money. He probably knew nothing about the press: born in Brattleboro (Vermont), he had begun his career as a drugstore clerk, before making his fortune in bronze production in New Jersey after 1867 (Cabot, 1922). ${ }^{2}$ Hopkins would later create the American Relief Society in Paris, and fund "La Providence" hospital in Dinard (Brittany), where he spent his summers. ${ }^{3}$

9 The company "S.S. Chamberlain and Co." was created in Paris in October $1883 .{ }^{4}$ The title of the paper would be The Morning News, the same name as the paper founded in Connecticut a few years earlier by Briggs Reuben Davenport, another American journalist called on by Chamberlain to run the editorial staff of The Morning News. ${ }^{5}$ Briggs Davenport later wrote for the Daily Panama Star and Herald (1886), the Chronicle of San Francisco (1886-1887), the Morning News of New Haven (1890) and the Continental Daily Mail in Paris from 1914 to 1917. He also published a book about the war (A History of the Great War) in 1916. In Bordeaux, he was the editor of the American edition of $L a$ Petite Gironde in 1918-1919. After the war, he became the editor of the Parisian edition of the New York Herald. He died in March 1932.

10 The head office of the company was in the second district of Paris, near the opera house and the Paris stock exchange. Chamberlain owned $70 \%$ of the company and Hopkins $30 \%$. The interests for each shareholder were about 5\%. Le Matin, the French edition of The Morning News, was launched on 26 February 1884. The owners of the two newspapers confronted then the first difficulty: they needed a French-speaking team to publish Le Matin. An English journalist living in Paris, Alfred Edwards (1856-1914) ${ }^{6}$, drew 
their attention. He was a reporter at Le Figaro and wrote his articles with an American style (Livois, 1965, 356). Chamberlain asked Edwards to take control of the French staff of Le Matin. But he did not know that they hoped to use Le Matin to serve their own interests (Pinsolle, 2012, 55)... This choice was the first sign of the vulnerability of the American owners of The Morning News and its French edition. Because of the language, they depended on French journalists. And because of their lack of a social network in Paris, they were not able to find someone they could trust.

\section{The false "independence" of Le Matin}

\section{The importation of the American press into France}

The risks were all the more important because Chamberlain chose to import American journalism into Paris instead of adapting his newspaper to the French press model. In spite of the rise of the popular press (like Le Petit Journal), French journalism was still deeply linked to its political and literary tradition. It was the first time that a newspaper which claimed its "neutrality" so loudly was launched in France. Unlike French journalists, American journalists cared more about facts and news than commentaries and opinions (Schudson, 1978), even if the doctrine of "objectivity" was in its early stages in the United States (Summers, 1994; Blondheim, 1994). In order to publish scoops and exclusive news, the Morning News needed a special cable directly linked to London. This equipment was expensive: the price of the newspaper was 15 cents, while more and more popular dailies like Le Petit Journal sold for five cents thanks to the money from advertising. But the Morning News and Le Matin targeted a social elite interested in international news and financial markets.

Thanks to its "special cable" link with London, the Morning News got news from Central News, a British agency which was the rival of Reuters for more than ten years. Galignani's Messenger was directly threatened by the Morning News and won a judgment against Chamberlain in May 1884 because he had made a comparison between the number of the issues sold by the two papers in the Morning News. ${ }^{7}$ But Chamberlain's daily was better informed than the Galignani's. In addition to the special cable, the Morning News had its own correspondents in Berlin, Vienna, Istanbul and Saint Petersburg. The editors selected the news which could attract American and British readers and was totally independent from the French agency Havas and the other "allied agencies": Reuters (Great Britain), Continental (Germany) and Associated Press (United States), which had been coordinating their work since 1859 (and 1875 for the American agency). The first issue of Le Matin was not simply a French translation of The Morning News. Its price was only 10 cents, and the articles dealt more with financial markets and French events. The two titles could get international news as fast as the big agencies (Palmer, 1983, 114-15). Havas was really worried about these newspapers. In November 1883, the director of the firm, Édouard Lebey, wrote to baron H. Reuter:

I am seeing like you the development of a big organization based on special international cables and linked to the New York Herald, Central News or the Morning News, and new rivals will probably appear and surprise us very soon. ${ }^{8}$

Havas had serious reasons to be worried. Le Matin published exclusive news (about French colonial operations in Tonkin or Madagascar for example) and claimed that it was able to publish at 7 am the news that Havas could transfer only at noon to the 
newspapers, which could publish their articles based on that news only in the evening or the next day. Furthermore, the new daily launched by Chamberlain asserted that it was more independent than the big agencies, accused of being controlled by governments. ${ }^{9}$

"Independence" was the key word in the columns of Le Matin, which was the first French daily to proclaim its political pluralism so loudly (Ferenczi, 1996, 13-15). The other newspapers were blamed for their political commentaries and their lack of honesty. For that reason, Le Matin was very original and even provocative in its first editorial:

Le Matin will not look like any newspaper and its program will not look like any other program ;

Le Matin will be a unique daily ;

A daily without political opinion;

A daily independent from banks and business ;

A daily independent from any literary tendency ;

A daily independent from any artistic group ;

A daily with telegraphic, universal and true news ;

A daily enemy of scandal ;

An honest, bold and absolutely independent daily.

But this declaration of intent should not hide the fact that Le Matin, like the other newspapers which claimed to be totally independent (Palmer, 1983, 19; Delporte, 1999, 52), was obliged to be politically oriented and to remain close to the centers of political power. Chamberlain's daily had to propose a moderate point of view in order to attract readers from the social elite. It also needed to maintain constant contact with politicians and particularly those in power in order to get the most recent news. That is why Le Matin's pluralism was above all a commercial argument and a way to distinguish itself from its rivals (Pinsolle, 2012, 57, 82-83).

\section{A newspaper managed as a business above all}

For Mackay and Bennett, The Morning News was only seen as an instrument to serve their business interests. With Chamberlain, Le Matin became a business in and of itself, which led him to define a commercial strategy based on the model of the US press and appeal to a wealthy readership. Le Matin repeated that it was a serious paper which wanted to inform, not to entertain. That is why no novels would be published. Only news and facts mattered. Political opinions were only penned by four editorial writers who represented four different political groups: Émmanuel Arène (a republican member of Parliament), Paul de Cassagnac (a member of Parliament who promoted Empire over Republic), Jules Cornély (a royalist journalist) and the famous socialist writer and journalist Jules Vallès. ${ }^{10}$

The British and American press supported Le Matin. The Times found it very original, but also very serious and very useful for all dailies published in the evening. ${ }^{11}$ The New York Times said the same thing and concluded that "its success would satisfy all good Americans. ${ }^{12}$ French newspapers were less enthusiastic and more critical. Le Journal des Débats was very surprised by the choice of four different editorial writers. ${ }^{13}$ Le Figaro underlined the fact that, contrary to appearances, this new daily was very serious. In $L a$ Bataille, the pluralism of Le Matin was compared to the fog in London. ${ }^{14}$ 

circulation of the big Parisian newspapers: 584000 copies for Le Petit Journal, 196000 for La Petite République, 151000 for La Lanterne, 105000 for Le Figaro, 100000 for Le Petit Moniteur. There were also a lot of newspapers whose circulation was between 20000 and 70000 copies, like Le Temps, L'Intransigeant, Le Petit Parisien, Le Rappel, Le Petit National (Albert, 1972, p. 234). Chamberlain understood that Le Matin could have a much larger audience than the Morning News just because it was in French. He decided to focus on Le Matin and created a new company with his associate Hopkins in June $1884 .{ }^{15}$ Chamberlain still owned $70 \%$ of this public company, whose headquarters was in the first district of Paris (at 25, rue d'Argenteuil). With the exception of Albert Chester Ives, a well known English-American journalist (Morison, 1971, 100), we know almost nothing about the six other shareholders: Fanny Atwill (Isaac Bate's widow), Théodore Brooks, Marie Adams (Théodore Brooks Sr.'s widow), William Chambers Williams and George Spencer Payne (presented as a journalist) ${ }^{16}$

The Morning News was sold to Albert Chester Ives, and then merged with The American Register, a weekly publication (Morison, 1971, 100). Mackay didn't need a French newspaper anymore because he had already succeeded in breaking the monopoly of Western Union by that time (Griset, 1996, 97). Some historians say that Mackay and his associate James Fair later conspired with agents of Louis Napoleon (1856-1879), the son of Napoleon III, to corner the world wheat market, and that they used Le Matin to reach this goal (Lundberg, 1936, 26; Featherston, 1978, 38-42). We know that the Nevada Bank, founded by Mackay and his associates, failed to control the wheat market in 1887, but we haven't found anything which could prove that Le Matin was involved in this operation. ${ }^{17}$ As for Bennett, he moved the New York Herald from London to Paris in 1887 and preferred to use this famous and powerful paper against the big news agencies (Palmer, 1983, 132).

\section{Money is not enough: the "American" Matin's failure}

\section{The Coudert brothers' network.}

The new public company created by Chamberlain attracted new American businessmen: the Coudert brothers, famous international lawyers from New York, whose office existed until 2006. The Coudert brothers probably met Chamberlain through Mackay, who was one of their clients (Conard, 1995, 1725). The new company of Le Matin was created in their Parisian office. ${ }^{18}$

21 The links between the Coudert brothers and France were old. Their father, Charles Coudert (1795-1879), was a member of the Guard of Honor in Napoleon's Army during the Napoleonic Wars. In 1821, he conspired to make the son of Napoleon king of France in place of Louis XVIII, but was sentenced to death and had to flee France. He moved to New York in 1824, where he opened a French school (MacAdam et al., 1897, 103). ${ }^{19} \mathrm{His}$ first son, Frédéric-René (1832-1903), studied law at Columbia College and set up a law office with his brothers, Charles Jr. (1833-1897) and Louis-Léonce (1836-1883) in 1853.

The Coudert brothers office, which specialized in international affairs, became one of the most important American law offices. At the end of the 1870's, the Coudert brothers created an office in Paris. In 1879, Edmond Kelly, a lawyer from New York born in France in 1851 (at Blagnac), was sent to run this French office. Kelly left the Coudert 
brothers to create his own office in 1884 (Veenswijk, 1994, 56). ${ }^{20}$ Another lawyer from New York with French origins, the young Henry Cachard, took his place. ${ }^{21}$

In 1885, the Coudert brothers, Edmond Kelly and Henry Cachard took shares in the company "Le Matin." Another lawyer from New York, William Morton Grinnell, invested money in this newspaper. Grinnell was only 27 years old. He had been working as a counsel at the American Legation in France for three years. He was the nephew of the American Ambassador in France: Levi P. Morton. ${ }^{22} \mathrm{He}$ probably knew Kelly, because the two men studied law in Paris at the same time.

Excluding Chamberlain and Hopkins, all the shareholders of Le Matin were linked to the Coudert brothers. Even Charles Allen Thorndike Rice (1851-1889), director of the North American Review, who took shares in Le Matin in 1885, was probably in contact with them. Rice was a friend of Prince Napoléon's (1822-1891), cousin of Napoléon III. ${ }^{23} \mathrm{We}$ know that the father of the Coudert brothers, Charles Coudert, was very close to the Bonaparte family. We can imagine that Rice and the Coudert brothers knew each other, which could explain the presence of Rice among the financial backers of Le Matin.

\section{The goals of the American shareholders: money and influence in France.}

The new shareholders of Le Matin were important businessmen. From 1885 to 1888 , Frédéric-René Coudert was one of the directors of the Union Pacific Railroad Company, owned by Jay Gould, and was probably involved in American banking and insurance companies at the same time..$^{24}$ William Morton Grinnell had the same ambitions and became director of railroad and banking companies (Illinois Railroad, Rio Grande and Sierra Madre Railroad, Mt Morris Bank). ${ }^{25}$

But making money with Le Matin was not the only motivation of these American businessmen. The Coudert brothers had just opened their Parisian office in 1879. We can easily understand that they were interested in using a French newspaper to develop their activities in France, all the more so as the creation of a branch office in Paris was a "quite unprecedented idea" in "the climate of American law practice of the age" (Veesnwijk, 1994, 56). In addition, they were linked to the construction of the Panama Canal, which had just started three years earlier. The archives of the Company of the Panama Canal show that the Panama Railroad Company, founded by Americans, was a client of the Coudert brothers. Charles Coudert Jr. was a shareholder and, from 1888, the vice-president of the company. ${ }^{26}$ As for Edmond Kelly, he was the lawyer for the American Contracting and Dredging Company, founded in 1882 by the Slaven brothers, who were important investors in the construction of the Panama Canal. ${ }^{27}$ The company in charge of this construction was founded in 1880 by Ferdinand de Lesseps. In this situation, a French newspaper could be used to promote this French company and convince the French people to invest money in the project.

The press was a good investment: French newspapers became more and more profitable at the end of the nineteenth century. A lot of them were public companies quoted on the Stock Exchange, like Le Siècle, Le Figaro, Le Petit Journal, Le Temps, Le XIXe Siècle, and most of Republican newspapers (Pradié, 1994, 73). Many dailies could sell at only 5 or 10 cents thanks to advertising revenues, which represented probably $30 \%$ of the revenues of Le Matin in $1884 .{ }^{28}$ Newspapers were considered as commercial goods 
and were run to make money. Former Prime Minister Jules Simon explained this evolution in Le Matin in August 1884:

Today, political parties don't create papers anymore. Bankers do that. They launch them to make profits. They choose a political orientation which can attract shareholders. ${ }^{29}$

Beginning in 1881 with the adoption of the law on freedom of speech, the number of newspapers increased. Le Matin had to be clearly distinguishable from the popular press (like Le Petit Journal) and bourgeois newspapers (like Le Temps or Le Journal des Débats). The choice of the price (10 cents) was very risky: 5-cent newspapers represented three quarters of the total circulation of the whole Parisian press in 1880. Furthermore, there were 90 dailies in Paris and 252 in the other towns in 1882. In this context, Chamberlain focused on international news, because it was one of the big weaknesses of the French press. Five-cent dailies had no foreign correspondent, and Le Temps and Le Figaro were the only papers with a correspondent in London in 1885 (Albert, 1972, p. 119). That's why Le Matin invested money in its foreign news capabilities. 37\% of its total expenses were dedicated to its editorial staff in 1896 (thirty years earlier, these expenses represented only $5 \%$ of the total costs of Le Petit Journal). Around 50 journalists worked for Le Matin in 1892 (Dubief, 1892, 109). This editorial staff was one of the most numerous, and Chamberlain's daily could be compared to such major newspapers as Le Figaro, L'Écho de Paris or Le Journal.

\section{The end of the "American" Matin}

In August 1884, the editor of Le Matin, Alfred Edwards, was dismissed by the American directors. The official reason was that he didn't respect the rule of political neutrality. ${ }^{30}$ In reality, the editor of Le Matin had wanted to take complete control of the newspaper, and the American directors preferred to dismiss him probably for this reason. ${ }^{31}$ Edwards created with the French staff another newspaper called Le Matin français, and explained that he left Le Matin because of his patriotism. ${ }^{32}$ But Le Matin français disappeared after eleven weeks because Edwards did not have enough money to continue publication. After they won a court case against him, the American directors, aware of the professional talents of Edwards and worried about the lack of popularity of Le Matin, decided to reinstate Edwards, who became editor again and took shares in the company. ${ }^{33}$ At the end of 1884, half of the board of directors was French. Edmond Kelly disagreed with this course, because he thought that the company should stay under the control of the Americans. ${ }^{34}$ In September 1885, due to the lack of profitability of Le Matin, a second company, in charge of the commercial exploitation of the newspaper, was created. Edwards funded it with money given by his father. The first company was still owned by Chamberlain. ${ }^{35}$

Between the end of 1885 and the summer of 1890, the American shareholders seemed to let Edwards do his job without interfering. But they couldn't use Le Matin to reach their goals anymore. In June 1885, while remaining the owners of the daily, they were obliged to let Edwards create a new company to run Le Matin because of their financial difficulties. From that date, the Parisian editor could use the newspaper to defend his own interests and was not reluctant to earn money using blackmail (Pinsolle, 2012, 49-67). In July 1890, Edmond Kelly and other shareholders started to sell shares of the first company to Edwards, who took complete control of the newspaper ${ }^{36}$. As for 
Chamberlain, he probably still had shares in the company, but he returned to the United States in 1888 and worked until the end of his life for William Randolph Hearst in San Francisco (Featherston, 1978, 42).

31 Edmond Kelly, who worked as a lawyer at the American Legation in Paris, came back to New York in 1891, five years after Grinnell. ${ }^{37}$ The names of Henry Cachard and the Coudert brothers disappear from the archives of Le Matin after 1889. ${ }^{38}$ The Coudert brothers office was run by the son of Frédéric-René (Frédéric Jr.) after 1890 and was in a very difficult situation at that time (Veenswijk, 1994, 111). Maybe the evolution of the office explains why the Coudert brothers left Le Matin at the end of the 1880's. William Alonzo Hopkins, the first associate of Chamberlain, left his post of Director to a friend of Edwards in August 1890: the “American" Matin didn't exist anymore. ${ }^{39}$

\section{Conclusion}

The story of the "American" Matin is ambiguous. On the one hand, John Mackay and James Gordon Bennett Jr. reached their goals: the Commercial Cable Company was a success and the Morning News was independent from the big news agencies. On the other hand, the second generation of American shareholders, the Coudert brothers network, did not succeed in having an influence in Paris. This failure was due to two different problems. First of all, Le Matin was not popular enough, because of its originality and its price. In addition, the American directors were dependent on French journalists to publish Le Matin. For that reason, they very quickly lost the control of the newspaper, which was in fact run by Alfred Edwards. The story of the "American" Matin proved that money was not enough to be powerful in a foreign country. The American businessmen involved in this newspaper were not integrated into the Parisian elite, unlike James Gordon Bennett Jr., who succeeded in publishing the New York Herald Tribune in Paris after 1887. Edwards was very close to the politicians of the Third Republic and could use Le Matin to blackmail his enemies with complete impunity. Even if he did not have as much money as Chamberlain, his relations with French ministers and deputies made him much more powerful than the American directors.

ALBERT, Pierre, "La presse française de 1871 à 1940," in BELLANGER Claude, GODECHOT Jacques, GUIRAL Pierre et TERROU Fernand (dir.), Histoire générale de la presse française, vol. III : de 1871 à 1940, Paris, PUF, 1972, $688 \mathrm{p}$.

BLONDHEIM, Menahem, News over the Wires: The Telegraph and the Flow of Public Information in America, 1844-1897, Harvard University Press, 1994, 318 p.

САВОТ, M. R., "William Alonzo Hopkins," in Annals of Brattleboro, vol. II, E.L. Hildreth and Co, Brattleboro, Vermont, 1922.

CHATEAUBRIAND, François-René de, Mémoires d'outre-tombe, tome IV, Paris, Garnier frères, 1898.

CONARD, A.F., "Cook and the corporate shareholder: a belated review of William W. Cook's

publications on corporations," Michigan Law Review, vol. 94, 1995, p. 1724-1738.

COOPER-RICHET, Diana, "Les Galignani : libraires, éditeurs, hommes de presse, artisans d'une entente cordiale culturelle," in COOPER-RICHET Diana et RAPOPORT Michel (dir.), L'Entente cordiale. Cent ans de relations culturelles franco-britanniques, Paris, Créaphis, 2006, 390 p., p. 39-51. 
CROUTHAMEL, James L., Bennett's New York Herald and the rise of the popular press, Syracuse, Syracuse University Press, 1989, 202 p.

DUBIEF, Eugène, Le journalisme, Paris, Hachette, 1892, 313 p.

FEATHERSTON, James S., "Samuel S. Chamberlain," in Dictionary of Literary Biography, vol. XXV, Detroit, Gale Research, 1978.

FERENCZI, Thomas, L'invention du journalisme en France. Naissance de la presse moderne à la fin du XIXe siècle, Paris, Payot, 1996, 276 p.

GRISET, Pascal, Entreprise, technologie et souveraineté : les télécommunications transatlantiques de la France (XIXe-XXe siècles), Paris, Éditions Rive Droite, 1996, 735 p.

JoHnson, Allen (et al.) (ed.), Dictionary of American Biography, , London, H. Milford, Oxford University Press; New York: C. Scribner's sons, 22 vol. 1928-1958.

LIVoIs, René de, Histoire de la presse française, Paris, Société française du livre, 1965, 664 p. LUNDBERG, Ferdinand, Imperial Hearst. A social biography, New York, Equinox Cooperative Press, 1936, $406 \mathrm{p}$.

MAKLEY, Michael J., John Mackay: Silver King in the Gilded Age, Reno, University of Nevada Press, 2009,270 p.

MCADAM, David et al., History of the bench and bar of New York, vol. II, New York, New York History Company, 1897, $404 \mathrm{p}$.

MORISON, Stanley, The History of The Times, vol. III: The Twentieth Century Test, 1884-1912, London, Kreus Reprint, 1971

O'CoNNOR, Richard, The Scandalous Mr. Bennett, Garden City, Doubleday, 1962, 335 p.

PALMER, Michael B., Des petits journaux aux grandes agences. Naissance du journalisme moderne, Paris, Aubier, 1983, $350 \mathrm{p}$.

PINSOLLE, Dominique, Le Matin (1884-1944). Une presse d'argent et de chantage [Press, Money and Blackmail : Le Matin (1884-1944)], préface de Christian Delporte, Rennes, Presses universitaires de Rennes, coll. Histoire, 2012, 354 p.

PRADIÉ, Christian, La presse, le capitalisme et le lecteur. Contribution à l'histoire économique d'une industrie culturelle, 2 vol. , PhD dissertation in Information and Communication Sciences, Advisor : prof. Bernard Miège, University of Grenoble-3, 1994, 814 p.

SCHUDSON, Michael, Discovering the News : a Social History of American Newspapers, New York, Basic books, 1978, $228 \mathrm{p}$.

SUMMERS Mark W., The Press Gang : Newspapers and Politics, 1865-1878, University of North Carolina Press, 1994, 405 p.

SMITH, Grant Horace, V. TINGLEY Joseph, The History of the Comstock Lode, 1850-1997, Reno, University of Nevada Press, 1998, 328 p.

The National Cyclopaedia of American Biography, vol. XIV, New York, James T. White and Company, 1910.

The New International Year Book. A compendium of the World's Progress for the Year 1928, New York, Dodd, Mead and Company, 1929, 910 p. 
VEENSWIJK, Virginia Kays, Coudert Brothers. A Legacy in Law: the History of America's First International Law Firm, 1853-1993, New York, Truman Talley Books, 1994, 448 p.

Who was who in America: a Companion Volume to Who's Who in America. 1: 1897-1942: Biographies of the Non-Living with Dates of Deaths Appended, Chicago, Marquis, 1943.

\section{NOTES}

1. The International Herald Tribune was renamed The International New York Times in October 2013.

2. AN, LH 1308/12, Legion of Honour file of William Alonzo Hopkins; The New International Year Book. A Compendium of the World's Progress for the Year 1928, New York, Dodd, Mead and Company, 1929, 910 p., 331.

3. Time, March 12, 1928.

4. Archives of the Commercial Court of the Seine 㞓CCS㹂, D31 U3/546 : file 2165.

5. Who was who in America: a Companion Volume to Who's Who in America. 1: 1897-1942: Biographies of the Non-Living with Dates of Deaths Appended, Chicago, Marquis, 1943.

6. Edwards acquired the French nationality at the end of the 1880's.

7. Journal des Tribunaux de Commerce, vol. XXXIII, Paris, A. Chevalier-Marescq, 1884, 607.

8. AN, 5 AR 64, E. Lebey to H. de Reuter, November 8, 1883 (quoted in Palmer, 1983, 115.)

9. Le Matin, August 8, 1884.

10. Le Matin, February $26,1884$.

11. Quoted in Le Matin, February 28, 1884.

12. Ibid.

13. Ibid.

14. Quoted in Le Matin, 27 février 1884.

15. National Archives of France 壏NA 21,1884 .

16. CCS, D 31 U3 560/1284, creation of the public company "Le Matin", June 21, 1884.

17. About this operation, see The New York Times, August 9,1887.

18. CCS, D 31 U3 560/1284, Public company "Le Matin", June 21, 1884.

19. François-René de Chateaubriand has written about Charles Coudert in Mémoires d'outre-tombe, tome IV, Paris, Garnier frères, 1898, 465-66.

20. NA, LH 1396/38, Legion of Honour file of Edmond Kelly; The National Cyclopaedia of American Biography, vol. XIV, New York, James T. White and Company, 1910, 222.

21. NA, 1 AR 1 , General meetings of the company "Le Matin".

22. Who was who in America, op cit., 490.

23. "Rice, Charles Allen Thorndike", in Dictionary of American Biography, edited by Allen JoHnson (et al.), London, H. Milford, Oxford University Press, New York, C. Scribner's sons, 22 vol. 1928-1958.

24. Who was who in America, op.cit. , 265. The New York Times (December 21, 1903) mentions, without any date, the New York Security and Trust Company, the Washington Life Insurance Company, the Emigrant Industrial Savings Bank and the St Patrick's Cathedral.

25. Who was who in America, op cit., 490. No date mentioned. 
26. NA, 7 AQ 33, Report of the Panama Railroad Company for the year 1893, New York Times, December 4,1892 .

27. NA, 7 AQ 12, Contract between Achille Monchicourt and Henry Bartholomew Slaven, President of the American Contracting and Dredging Company, represented by Edmond Kelly, December 30, 1890; The national Cyclopaedia of American biography, vol. XIV, op. cit., 222.

28. We don't know the advertising revenues for the years $1884-1886$, but we know that $37 \%$ of the revenues came from advertising int 1886 (NA, 1 AR 1, GA, June 5, 1887).

29. Le Matin, August 12, 1884.

30. Le Matin, August 3, 1884.

31. NA, 1 AR 3, General meeting of the company "Le Matin", August 14, 1890.

32. Le Matin français, August 2, 1884.

33. NA, 1 AR 1, General meeting of the company "Le Matin", November 3, 1884.

34. NA, 1 AR 1, General meeting of the company "Le Matin", March 20, 1885.

35. NA, 1 AR 2, Board of Directors of the company "Le Matin", September 6, 1885.

36. NA, 1 AR 3, General meeting of the company "Le Matin", August 14, 1890.

37. NA, 1 AR 3, General meeting of the company "Le Matin", August 14, 1890 ; The New York Times, February 10, 1892 and December 13, 1903. Edmond Kelly, The national Cyclopaedia of American biography, op. cit., 222. Kelly was interested in socialism and created in 1892 the City Club in New York (NA, LH 1396/38). Grinnell received the Legion of Honour in 1890 (NA, LH 1944/10). After 1893, he worked in the banking company Morton, Bliss and Co., cretaed by his uncle.

38. Cachard ran the French office of the Coudert brothers firm until World War I. He was the author of the first English traduction of the French civil code, in 1895.

39. NA, 1 AR 2, Board of Directors of the company «Le Matin », August 10, 1890. Hopkins created later the American Relief Society in Paris, and funded, during Word War I, the hospital «La Providence » in Dinard, where he used to spend time in summer (САВОт M. R., « William Alonzo Hopkins », op. cit.).

\section{ABSTRACTS}

Le Matin (1884-1944) was the first French daily with an American style. This newspaper is wellknown as one of the most important French papers published between the end of the nineteenth century and 1944. What is less well-known is that it was first backed by American interests. These American businessmen wanted to control a Parisian daily to make money and to promote their business projects. But they became very quickly unable to reach their goals in France and were forced to leave Le Matin and to sell it to its Parisian editor.

Le Matin (1884-1944) est le premier quotidien “à l'américaine”. lancé en France. Connu comme un des plus importants journaux français de la première moitié du XXe siècle, on sait moins qu'il fut, à ses débuts, directement financé par des hommes d'affaires américains. Ces derniers souhaitaient à la fois profiter d'une entreprise qu'ils espéraient rentable et défendre leurs projets industriels et commerciaux. Mais, très rapidement, Le Matin échappa à ses bailleurs de fonds américains, qui ne réussirent pas à s'imposer en France et furent contraints d'abandonner le titre à son rédacteur en chef parisien. 
INDEX

Mots-clés: entreprises de presse, journalisme américain et français, transferts culturels, réseaux d'affaires

Keywords: Press industry, American and French journalism, Cultural transfers, Business networks

\section{AUTHOR}

DOMINIQUE PINSOLLE

Université Bordeaux-Montaigne 